\author{
Mirosław Karwat \\ ORCID: 0000-0002-6778-6787 \\ Uniwersytet Warszawski
}

\title{
O działaniach politycznych i pokrewnych. Glosa do typologii Andrzeja Czajowskiego
}

DOI: $10.19195 / 1643-0328.27 .2$

Słowa kluczowe: polityka, polityczność, upolitycznienie, teoria polityki, działania stricte polityczne, działania quasi-polityczne, działania okołopolityczne

\section{Wprowadzenie}

Artykuł jest komentarzem metodologicznym do typologii działań obecnych w życiu politycznym społeczeństw, przedstawionej przez Andrzeja Czajowskiego w postaci triady: działania (stricte) polityczne, działania quasi-polityczne oraz działania okołopolityczne. Każdy z wyróżnionych typów został ponadto skonkretyzowany w systematycznym katalogu rodzajów i zakresów działania.

Profesor Andrzej Czajowski należy do podwójnie wąskiego i - nie bójmy się tego słowa: ekskluzywnego - kręgu w polskim środowisku politologów, jaki tworzy nieliczna grupa badaczy pasjonujących się teorią polityki. I to teorią polityki samą w sobie, a nie przygodnie, dygresyjnie, przy okazji dociekań i poszukiwań na gruncie badań „konkretnych" czy szczegółowych. Zresztą również tych politologów, których zainteresowania badawcze owocują takimi czy innymi komentarzami teoretycznymi i przyczynkarskim wkładem do teorii polityki, jest niewielu.

$\mathrm{W}$ tym kręgu badaczy wyspecjalizowanych $\mathrm{w}$ teorii polityki (teorii rozumianej zarówno w rygorystycznych kategoriach logiki i metodologii nauk, jak i rozumianej luźniej jako typ refleksji eksplanacyjnej i heurystycznej, często na pograniczu z filozofią polityki $\left.{ }^{1}\right)$ również niewielu jest takich uczonych, którzy wnoszą do niej wkład autorski.

${ }^{1}$ Por. na temat rozumienia teorii B. Krauz-Mozer, Teorie polityki, Warszawa 2005; Czym jest teoria w politologii?, red. Z. Blok, Warszawa 2013; T. Klementewicz, Rozumienie polityki. Zarys metodologii nauki o polityce, Warszawa 2010. 


\section{Pochwała autorskiego stylu teoretyzowania}

Zwróćmy uwagę na istotną różnicę - między zaj mowaniem się teorią polityki (kiedy badacz pochyla się nad „dyskursem teoriopolitycznym” z pozycji sprawozdawczych, interpretacyjnych, porównawczych, komentatorskich, polemicznych; niekoniecznie z widocznym wkładem własnym, „wartością dodaną” od siebie) a uprawianiem teorii polityki. W drugim wypadku mamy do czynienia $\mathrm{z}$ oryginalną inwencją pojęciową, z całościową własną koncepcją odpowiadającą na pytanie, czym jest polityka i co jest polityczne, z systematyką „materii polityki” według własnych założeń autora, w których pozostaje konsekwentny ${ }^{2}$.

W tradycji i w praktyce badawczej nauki o polityce takie autorskie, „systemotwórcze" podejście występuje zarówno w postaci swoistej kodyfikacji problemów, pojęć i twierdzeń, która ma mieć walory syntezy o prawidłowościach rządzących polityką ${ }^{3}$, jak i w postaci namysłu nad specyfiką, kryteriami i granicami tożsamości zjawisk politycznych, przesłankami rozgraniczenia między tym, co jest ściśle i wyłącznie polityczne, a tym, co z polityką się styka, przenika lub jest w nią zaplątane $e^{4}$.

Teoriopolityczne prace Andrzeja Czajowskiego - szczególnie z ostatniej dekady — mają właśnie takie walory. Są autorską próbą i propozycją syntezy w kwestiach dla teorii polityki kluczowych, takich jak: definicja polityki, kryteria „polityczności”, granice między tym, co polityczne, a tym, co „niepolityczne” lub „niezupełnie polityczne”, lub „nie tylko polityczne".

Na marginesie można by rzec, iż takim kompleksowym odniesieniem się do tego właśnie rdzenia teorii polityki i przedstawieniem swego stanowiska w formie scalonej wykładni profesor zawstydził swych kolegów (łącznie ze mną), skupionych od dawna na tych właśnie kwestiach, lecz wypowiadających się na ten temat w formie rozproszonej w artykułach, w pewnych wątkach monografii czy rozpraw, lecz nie w jednym miejscu z kompleksowym wykładem credo. Sam w sobie ten akt odwagi intelektualnej zasługuje na uznanie i naśladownictwo, gdyż - przyznajmy z dystansu - niewiele przecież pozostaje z twórczości naukowej, która płynie wartko ze strumieniem kolejnych punktowanych, acz banalnych i „przeglądowych” artykułów niewnoszących nowej jakości. Po

2 Przykładem takiego autorskiego, a przy tym kodyfikującego stylu uprawiania teorii polityki są we współczesnej literaturze rodzimej - oprócz prac Andrzeja Czajowskiego - dociekania i poszukiwania Zbigniewa Bloka. Zob. idem, O polityczności, polityce i politologii, Poznań 2009.

3 Takie ambicje miał swego czasu Artur Bodnar (zob. idem, Decyzje polityczne. Elementy teorii, Warszawa 1985; idem, Ekonomika i polityka. Podstawowe zależności, Warszawa 1980) oraz skupiony wokół niego Zespół Teorii Polityki w COM SNP, do którego miałem zaszczyt należeć. Prace tego zespołu (zob. np. Elementy teorii polityki, red. K. Opałek, Warszawa 1989) były o krok od powstania szkoły naukowej. Dziś zapomniane lub wstydliwie przemilczane na zasadzie „wylania dziecka z kąpielą” z powodu „obciążeń ideologicznych”.

${ }^{4} \mathrm{~W}$ tym zadaniu klasykiem i wciąż żywym inspiratorem pozostaje Carl Schmitt ze swoją rozprawą Begriff des Politischen. Zob. idem, Teologia polityczna i inne pisma, Kraków 2000. Nieprzypadkowy jest renesans zainteresowania jego koncepcją polityczności, uwidoczniony między innymi serią prac autorstwa lub powstałych w kręgu Chantal Mouffe. Zob. Carl Schmitt. Wyzwanie polityczności, red. Ch. Mouffe, Warszawa 2011. 
latach nie ma śladu po pracy naukowej tego czy innego autora, jeśli nie przeprowadził porządnego poznawczego remanentu swoich poszukiwań, ustaleń, dokonań.

Autorskie syntezy - zwłaszcza wyłożone w tak klasycznej formie gatunkowej jak tezy ${ }^{5}$ - mają zaś ten walor i pożytek dla całej wspólnoty uczonych w danej dyscyplinie czy specjalności, że są dla kolegów z „konkurencji”, a także fanów danego twórcy wyzwani em. Stwierdzenia wyraźne - co jak rozumieć, co jest czym, jak odróżnić podobne lub pokrewne typy zjawisk, jakie zachodzą prawidłowości - zmuszają do przemyślenia, rozważenia, weryfikacji, nierzadko do polemik. Żaden teoretyk traktujący swoją problematykę (a poniekąd i swoje poglądy na dany temat) poważnie nie może ich zbyć - czy to kurtuazją, czy wyniosłym przemilczeniem (na zasadzie „ja tam wiem swoje i robię swoje”), lecz musi się z nimi zmierzyć. I właśnie ta konieczność jest sama w sobie wartością w życiu naukowym (jako impuls do myślenia, zwłaszcza do wyrwania nas z inercji rzekomych oczywistości), a zasługą autora-, prowokatora”.

W tym kontekście odniosę się do oryginalnej autorskiej systematyki rodzajów działań występujących w życiu politycznym, jaką przedstawił Andrzej Czajowski w postaci triady: działania stricte polityczne, działania quasi-polityczne oraz działania okołopolityczne.

Koncepcję, a następnie trójczłonową i jeszcze konkretyzowaną typologię działań politycznych przedstawił, rozwinął i skonkretyzował Andrzej Czajowski w kilku kolejnych publikacjach: w rozdziale Polityczność działań społecznych w pracy zbiorowej Polityka i polityczność. Problemy teoretyczne i metodologiczne (Wrocław 2012), której był współredaktorem; w monografii Decydowanie w polityce (Wrocław 2013); w artykule Polityczność działań dziennikarza w świetle teorii konfliktu społecznego („Studia Politologiczne” 37, 2015); w rozprawie $X$ twierdzeń o polityce (Toruń 2015).

Streszczając w uproszczeniu: Działania stricte polityczne przypisuje Czajowski ściśle i formalnie rozumianym podmiotom polityki; działania quasi-polityczne - pozostałym, nieformalnym, czasem tylko okazjonalnym uczestnikom polityki, niezaabsorbowanym polityką samą w sobie; działaniami okołopolitycznymi nazywa te, które są realizacją celów politycznych (ale za pośrednictwem rozmaitych instytucji, agend, zrzeszeń „niepolitycznych”, na przykład administracyjnych) w różnych sferach życia społecznego $^{6}$. Sądzę, że tym skrótem nie wypaczyłem zastosowanych kryteriów. Zachęcam jednak czytelników do zagłębienia się w zniuansowany wywód autora.

Tę typologię (sam autor traktuje ją słusznie jako typologię, a nie klasyfikację) uważam za inspirującą, nader pomocną w uporządkowaniu opisu (diagnozy, kwalifikacji), a także wyjaśnianiu działań zaliczanych do sfery polityki. I to pomimo że Andrzej Czajowski konstruuje ją z pozycji podejścia klasycznie „kratocentrycznego”, podczas gdy ja opowiadam się za optyką „,socjocentryczną"7.

5 A. Czajowski, X twierdzeń o polityce, Toruń 2015.

${ }^{6}$ A. Czajowski, Decydowanie w polityce, Wrocław 2013, rozdz. II; A. Czajowski, X twierdzeń..., Twierdzenie VI, Twierdzenie VII.

7 Trafne rozróżnienie „kratocentrycznego” ujęcia polityki (opartego na uznaniu czynnika władzy za kluczowy w genezie i funkcjonowaniu polityki, a pojęcia władzy w państwie za punkt wyjścia w samej definicji polityki) oraz „socjocentrycznego” (skupionego na grze interesów i dążeń społecznych) sformułował Mariusz Gulczyński. Zob. idem, Politologia. Podręcznik akademicki, Warszawa 2010, wykład 12. Alternatywne orien- 
Swą systematyką Czajowski niejako przeciwstawił się utrwalonym potocznym czy gazetowym kwalifikacjom działań występujących w sferze polityki, które oscylują między intuicyjnym poczuciem oczywistości, co jest polityczne (na zasadzie „koń jaki jest, każdy widzi" lub według kryterium miejsca), a mętnym blankietowym podejściem „okolicznościowym” (z tezą: to zmienne okoliczności rozstrzygają, co w danej chwili jest polityczne; potencjalnie wszystko może być polityczne), które jest karykaturą wyrafinowanego antyformalizmu Carla Schmitta ${ }^{8}$. A przy tym - mimo podtrzymania „kratocentrycznego” rozumienia polityki (gdzie punktem wyjścia i układem odniesienia jest władza w państwie) - Czajowski wykracza poza wąski horyzont nachylenia „prawnopaństwowego", realistycznie traktując życie polityczne jako splot działań różnych podmiotów (nie tylko organów władzy, sił rządzących), w tym oddziaływań (nacisków społecznych, form oporu) na ośrodki władzy i decyzji. Aczkolwiek „kratocentrycznie” rezerwuje termin działania polityczne raczej dla inicjatyw i przedsięwzięć podmiotów władzy lub pretendentów do władzy. I w tym miejscu nasze poglądy się różnią.

Autor omawianej systematyki konstruktywnie odniósł się tu do kluczowych niuansów, jakimi są nietożsame podstawy i rodzaje związku typów działań różnych podmiotów z tym, co uznajemy za politykę. Ekspedycja badawcza w tym kierunku zasługuje na uznanie, a sformułowana przy tym koncepcja na poważne rozpatrzenie - także wtedy, czy zwłaszcza wtedy, gdy bądź w punkcie wyjścia, bądź w detalach wydaje się dyskusyjna.

\section{Teoriopolityczne znaczenie i walory tej propozycji}

Systematyka-triada Andrzeja Czajowskiego jest dla każdego teoretyka polityki bardzo inspirująca, choć z pewnością dyskusyjna w niuansach, o czym dalej.

Przede wszystkim jednak przypomina każdemu z nas, że w badaniu mechanizmów polityki nie unikniemy odpowiedzi na pytanie o „granice polityczności” $-\mathrm{w}$ tym wypadku o zakres terminu „działania polityczne”. Na marginesie zauważmy, że filozoficzno-estetyczne dociekania nad granicami polityczności ${ }^{9}$, choć także są inspirujące dla politologów i adaptowane w ich dociekaniach ${ }^{10}$, ukazują tylko jeden $\mathrm{z}$ aspektów zja-

tacje w politologii. Zob. też M. Karwat, O niezbędnym dopełnieniu optyki kratycznej w naukach o polityce, [w:] Nauki o polityce 2.0. Kontrowersje i konfrontacje, red. S. Sulowski, Warszawa 2018.

8 Antyformalistyczny, wręcz dialektyczny walor Schmittowskiego modelu konceptualnego poddałem analizie w pracy Cecha polityczności i dziedzina teorii polityki, [w:] Carl Schmitt a współczesna myśl politycz$n a$, red. R. Skarzyński, Warszawa 1996. Relacyjno-kontekstowy status ,polityczności” zjawisk akcentowany jest w pracach Ch. Mouffe - por. np. eadem, Polityczność, Warszawa 2008; eadem, Agonistyka. Polityczne myślenie o świecie, Warszawa 2015.

9 Przykład: modny autor J. Rancière, Dzielenie postrzegalnego. Estetyka jako polityka, Kraków 2007; idem, Na brzegach politycznego, Kraków 2008.

10 Zob. W poszukiwaniu polityczności, red. E. Jurga-Wosik, S. Paczos, R. Rosicki, Poznań 2014; Polityka/ polityczność. Granice dyskursu, red. B. Krzysztan, W. Ufel, M. Zieliński, Wrocław 2016; K. Minkner, Problem polityczności jako metateoretyczne wyzwanie dla politologii, „Athenaeum” 2014, nr 43; idem, Główne problemy konceptualizacji pojęcia polityczności, „Studia Politologiczne” 37 (Polityczność i polityka w refleksji teoriopolitycznej, red. B. Kaczmarek, M. Karwat), 2015. 
wiska, a zbyt dosłownie potraktowana delimitacja/separacja pojęcia polityki i pojęcia polityczności ${ }^{11}$ grozi ślepym zaułkiem. Ale to już temat do osobnej dyskusji.

Kiedy rozpatrujemy politykę jako określony sposób działania w danej sferze życia społecznego (specyficznej w porównaniu z ekonomiką, sferą kultury artystycznej, wierzeń i obrzędów religijnych) lub w określonym typie spraw wymagających rozstrzygnięcia, regulacji albo jako splot działań wielu podmiotów, już w punkcie wyjścia wita nas cała wiązka elementarnych pytań: Jakie i czyje działanie zasługuje na to, aby nazwać je politycznym? Czy sferę polityki tworzą (niejako tautologicznie) zjawiska (w tym ujęciu działania) z natury swej lub formalnie polityczne, a zwłaszcza czy tylko takie? A może raczej to, co polityczne nie ma własnego substratu, natomiast jest wypadkową i pochodną zmiennych w umiejscowieniu i formie napięć, sprzeczności, konfliktów społecznych ${ }^{12}$ ? Czy w takim razie nie jest tak, że działanie stricte polityczne albo „typowo polityczne" to tylko szczególny, lecz niejedyny komponent życia politycznego ${ }^{13}$ ? $\mathrm{Na}$ to ostatnie pytanie Andrzej Czajowski odpowiada twierdząco ${ }^{14}$, lecz właśnie dlatego zdaje się zmierzać do oddzielenia tego, co w swych źródłach i w sposobie istnienia jest niejako „czystą polityką", od tego, co jest w niej „domieszką" albo elementem zaplątanym lub nawet przypadkowym.

Andrzej Czajowski słusznie zakłada, że intuicyjno-potoczne rozumienie i przypisywanie działaniom ludzkim polityczności, ale i formalistyczne trzymanie się klucza instytucji państwowych i partyjnych powołanych i uprawnionych do działalności politycznej nie wystarcza, a przy tym zaciera różnicę między odmiennymi powodami do kojarzenia jednych, drugich i jeszcze innych działań z polityką. Co więcej, w kilku miejscach autor przyjmuje, iż wtedy gdy nie ma wątpliwości, że dane działanie jest działaniem politycznym, może być ono polityczne w mniejszym lub większym stopniu. W tym słusznie nawiązuje do Schmittowskiej oraz wyrosłej z marksizmu tezy o stopniowalnym charakterze lub natężeniu cechy polityczności ${ }^{15}$.

To istotny punkt zaczepienia - i punkt zgody w zestawieniu przynajmniej kilku koncepcji działań politycznych - że nie wszystkie działania polityczne są polityczne na tej samej zasadzie, w jednakowej formie i w tym samym stopniu.

W swej typologii-triadzie Andrzej Czajowski zmierzył się też - pomyślnie - z powracającym i nieuniknionym rozróżnieniem intencji działania oraz jego funkcji (czy to zaprogramowanej $\mathrm{w}$ danym systemie, czy też przejawiającej się bez przesądzenia z góry w postaci skutków, konsekwencji, reperkusji — również dysfunkcjonalnych), a także z rozgraniczeniem cech działania samego w sobie oraz jego kontekstu (społeczno-ekonomicznego, kulturowego, ideologicznego, prawnego). To jedna z przesłanek jego typologii. Drugą wydaje się nacisk na różnicę między działaniem politycznie

11 Założenie obecne w myśli Ch. Mouffe, przyjęte w rozprawie T. Mościcki, Polityka teatru. Eseje o sztuce angażujacej, Warszawa 2008, s. 17-18, podchwycone również przez Zbigniewa Bloka.

12 Teza przewodnia w koncepcji Carla Schmitta, paradoksalnie zignorowana nawet w kręgu entuzjastów jego relacyjno-sytuacyjno-kontekstowego rozumienia polityczności.

13 M. Karwat, O statusie pojęcia „polityczności”, „Studia Politologiczne” 37, 2015.

14 A. Czajowski, $X$ twierdzeń..., s. 108.

15 Zob. np. A. Bodnar, Decyzje polityczne..., s. 103-104. 
autotelicznym (w mechanizmie walki o władzę i reprodukcji lub zmiany władzy, ale i w wewnętrznym funkcjonowaniu instytucji politycznych), działaniem realizującym polityczną regulację i rozwiązywanie problemów i konfliktów społecznych oraz działaniem wyrażającym oczekiwania i roszczenia społeczne pod adresem ośrodków władzy, co koresponduje $\mathrm{z}$ anglosaską triadą politics, polity, policy.

Pokuśmy się teraz o namysł nad statusem poznawczym i zasadnością terminologii zastosowanej przez Czajowskiego; przy założeniu, że sama w sobie jest uzasadniona co najmniej w ramach jego spójnej i czytelnej koncepcji polityki oraz charakteru związków między tym, co formalnie jest „niepolityczne”, a polityką.

\section{Działania stricte polityczne}

Zastosowane w triadzie Andrzeja Czajowskiego określenie „działania polityczne” (po prostu polityczne, bez żadnych przedrostków) ${ }^{16}$ jest, o czym warto pamiętać w wypadku posłużenia się nim, skrótem myślowym. „Łopatologicznie” wykładając jego sens, musielibyśmy wyrazić się raczej tak: „działania stricte (ściśle) polityczne”, jak zresztą później uczynił sam autor w rozprawie $X$ twierdzeń o polityce.

Odpowiadałoby to innemu określeniu i rozróżnieniu o podobnej treści i podobnym punkcie wyjścia, mianowicie terminowi „działania o charakterze politycznym”, lub terminowi „działania z natury swej polityczne”, bo wyrażające istotę polityki, uwarunkowane immanentnymi mechanizmami polityki, łączące w sobie polityczne motywacje i intencje $z$ politycznymi funkcjami ${ }^{17}$. Chodzi tu o działania ściśle polityczne - jako typowe i specyficzne dla sfery polityki, charakteryzujące się adekwatnością politycznej formy do politycznej treści. Można i należy odróżniać je od działań niespecyficznych dla polityki (zarówno w formie, narzędziach, jak i motywacjach, intencjach, skutkach), zwłaszcza działań o raczej ubocznie niż wyłącznie lub głównie politycznym znaczeniu, lub działań, w których polityka jest nie „sednem sprawy”, lecz kontekstem przygodnym, okolicznościowym, a czasem nawet tylko okazją, pretekstem, instrumentem dla celów i potrzeb pozapolitycznych.

Terminologiczny skrót myślowy „działania polityczne” jest nader wymowny, gdyż zawiera w sobie sugestię, że na takie określenie zasługuje tylko rodzaj działań odpowiadających podanym przez autora kryteriom (działania poniekąd należące do zakresu właściwości „podmiotów politycznych"), ale w pewnym sensie paradoksalny. Mianowicie, epitet "polityczny” może tu być użyty „bez zbędnych dopowiedzeń", ale i bez zbędnych zastrzeżeń czy relatywizacji - właśnie dlatego że jego przyjęcie zostało poprzedzone zastrzeżeniami kryterialnymi dotyczącymi układu odniesienia.

16 A. Czajowski, Decydowanie w polityce..., s. 54 n.

17 Takich określeń - choć z kryteriami innymi niż w rozumieniu polityczności przez Czajowskiego używam w swoich artykułach: Polityczność i upolitycznienie. Metodologiczne ramy analizy, „Studia Politologiczne” 17 (Wyjaśnianie polityki, red. J. Błuszkowski, J. Zaleśny), 2010; O statusie cechy polityczności, „Studia Politologiczne" 37, 2015. 
Wyróżnienie i swoista nobilitacja działań ściśle i formalnie politycznych może sugerować rodzaj przesadnego optymizmu poznawczego, mianowicie przekonanie, że związek między typem podmiotu (sprawcy) a rodzajem, sposobem działania pozwala nam na jednoznaczne ustalenie, że to jest lub nie jest działanie polityczne.

W rzeczywistości jednak - i przekonujemy się o tym nieraz w diagnozie oraz w eksplanacji czynów ludzkich - kwalifikacja nie jest taka prosta i niezawodna. Najprostszy przykład: parlamentarna forma działania parlamentarzysty (uruchomienie i wykorzystanie procedur parlamentarnych, zwłaszcza inicjatyw ustawodawczych, ale też debat, interpelacji, nawet komisji śledczych) równie dobrze może być przejawem lobbingu (działanie polityczne o tyle, że polegające na zaprzężeniu instytucji politycznych do obsługi partykularnego interesu gospodarczego), a także realizacją celów ściśle politycznych związanych z utrwalaniem lub ograniczaniem władzy, z promocją praw i interesów określonej wielkiej grupy społecznej (na przykład etnicznej) lub z dyskryminacją mniejszości. Status podmiotu działania ani jego forma czy instrumentarium sam w sobie nie jest tu kryterium niezawodnym.

Uboczną słabością przyjętego przez Czajowskiego kryterium jest na przykład nieuwzględnienie sytuacji, gdy działanie formalnie polityczne (ze względu na jego formalny podmiot) w rzeczywistości ma sprawstwo tylko firmowane przez podmiot polityczny, a wyraża i realizuje pobudki i intencje niezupełnie „polityczne” albo nie powoduje żadnych istotnych skutków politycznych, nie rozwiązuje żadnego problemu politycznego (problemu władzy, kontroli władzy, oporu społecznego, modelu ustrojowego, alternatywy i zmiany politycznej). Bez żadnej złośliwości warto zauważyć na przykład, że niejedno działanie polityczne (spełniające wspomniane kryteria) w istocie jest tylko jałowym posunięciem lub gestem politykierskim ${ }^{18}$.

W tym kontekście należy wskazać pewną lukę w omawianej typologii. Jeśli jej zadaniem jest odróżnienie działań par excellence politycznych od działań - jak to określał swego czasu Artur Bodnar - tylko uwikłanych w politykę, to należałoby sformułowany katalog uzupełnić o jeszcze jeden typ, mianowicie działania pseudopolityczne, których cechą jest nieadekwatność, niewspółmierność „, hiperpolitycznej” formy do politycznej nieistotności, bezproduktywności; posługiwanie się — jako narzędziem - pozorami politycznych celów i zasad lub „polityczne” w formie rozgrywanie konfliktów i planów o znaczeniu jedynie kameralnym, partykularnym (na przykład czysto personalnych lub klikowych intryg w sferze ról i stanowisk „niepolitycznych”) ${ }^{19}$.

Zweryfikujmy zatem drugi człon triady.

18 Nieco zapomniane pojęcie politykierstwa przypominam w wywodzie O karykaturze polityki, Warszawa 2012, rozdz. 4. Por. też katalog form alienacji i bezproduktywności lub wręcz destrukcyjności w sposobie myślenia i działania polityków przedstawiony w rozprawie J. van Ginneken, The Psychology of Power. Temptations at the Top, London 2015. Zob. też K. Mroziewicz, Delirium władzy, Warszawa 2019; W.K. Szalkiewicz, W. Gałązka, Żądza rzadzenia. O władzy, polityce i politykach, Warszawa 2010.

19 Zob. M. Karwat, O karykaturze...., fragment pt. Pseudopolityka — lekcja z Kariery Nikodema Dyzmy. 


\section{Działania quasi-polityczne}

Do działań quasi-politycznych zaliczył Andrzej Czajowski trzy kategorie: działania o doniosłości politycznej, działania (podejmowane) z pobudek politycznych oraz działania upolityczniane ${ }^{20}$. To trafna konkretyzacja i dywersyfikacja tego typu. Ale - co zresztą zauważa sam autor - różnice i granice pomiędzy nimi są relatywne, płynne, niekiedy wręcz umowne ${ }^{21}$.

Działania o doniosłości politycznej oraz działania z pobudek politycznych - jako zbiory abstrakcyjnie możliwych przypadków - nie wykluczają się a priori. Mamy tu raczej częściowe przenikanie się zakresów. Doniosłe (znaczące) politycznie mogą być działania zarówno motywowane politycznie, jak i te pozbawione politycznej motywacji, kalkulacji czy intencji. Lecz i odwrotnie: działania o intencjach politycznych, nawet dużych ambicjach politycznych, mogą nie wywoływać ani praktycznie istotnych skutków politycznych, ani nawet rezonansu politycznego skutkującego wtórnie i pośrednio zmianami politycznymi; choć w niektórych wypadkach to się udaje. Ale - uwaga - taka „nierelewantność" może dotyczyć nie tylko działań podmiotów „niepolitycznych”. Niejedna inicjatywa partii politycznej czy uchwała, a nawet ustawa parlamentu zawisa w próżni społecznej. Niejedna prowokacja polityczna służb specjalnych lub afera medialna wywołana na zamówienie polityczne pozostaje bez echa.

Podobnie jest $\mathrm{z}$ rozgraniczaniem pierwszej i trzeciej subkategorii - działania mogą być upolityczniane właśnie dlatego, że mają (już widoczne lub potencjalne) istotne znaczenie polityczne.

Właśnie ta subtypologia ( $w$ ramach triady zasadniczej) potwierdza wyrażoną kwalifikację, że systematyka Andrzeja Czajowskiego ma charakter typologii, a nie klasyfikacji (czy to jednowymiarowej, czy też pogłębionej przez uchwycenie wewnętrznych zróżnicowań rozdzielnych w ramach wyodrębnionych klas wyjściowych) ${ }^{22}$. Nie jest bowiem tak, że te trzy subkategorie zostały wyróżnione według tego samego kryterium, lecz tak, że każda $z$ nich jest wyróżniona ze względu na inne, pozytywne (a nie rozdzielające, przeciwstawiające) kryterium. I każdy z tych subtypów interferuje z pozostałymi.

Do działań „up olitycznianych” (przez innych jako współuczestników życia politycznego) Czajowski zdaje się zaliczać tylko te, które same w sobie — bez „nagłośnienia”, określonego zinterpretowania i zdyskontowania, zaprzężenia do „cudzego rydwanu” nie musiałyby, może nawet nie mogłyby mieć w punkcie wyjścia lub uzyskać wtórnie politycznego znaczenia, a upolityczniane są w tym sensie również, że to inne podmioty przypisują im sens, cel polityczny, jakiego nie nadał im podmiot-sprawca, o czym decyduje pewien rodzaj okazji, możliwej użyteczności i korzyści. Trafnie jednak zauważa, że oprócz takiego instrumentalnego, a umyślnego upolitycznienia możliwe jest też upoli-

20 A. Czajowski, X twierdzeń..., s. 108.

21 Ibidem, s. 111-115.

22 Przejrzystą wykładnię różnicy między klasyfikacją a typologią zawiera fragment klasycznego podręcznika Z. Ziembiński, Logika praktyczna, Warszawa 2014, rozdz. V. Podział logiczny. 
tycznienie niezamierzone, a wymuszone przez pewne konieczności polityczne spowodowane danym działaniem ${ }^{23}$.

To dobry kierunek rozumowania i wysubtelnienia diagnoz oraz eksplanacji. Autor słusznie uznaje, że czym innym jest pierwotne (w punkcie wyjścia), a czym innym wtórne (i często tylko chwilowe, okolicznościowe) polityczne znaczenie takiego czy innego działania. Dodajmy jeszcze od siebie: czym innym jest polityczna autoteliczność (kiedy działanie służy celom politycznym jako takim, na przykład zdobyciu, umocnieniu władzy, zmianie ustroju, zwalczaniu kontrpretendentów do rządzenia, wykluczeniu pewnych sił z gry politycznej), czym innym polityczna in strumentalizacja (kiedy to, co niepolityczne w genezie, w intencjach, a nawet w skutkach czynimy narzędziem polityki) i jeszcze czym innym instrumentalizacja polityczności działań (kiedy to, przeciwnie, działania o celach i funkcjach politycznych są wykorzystywane w zupełnie innym, niepolitycznym celu, na przykład w strategiach osobistej kariery menadżera, promocji towarów lub „produkcji artystycznej” itd.) $)^{24}$.

W każdym razie autor typologii słusznie wziął pod uwagę, że czym innym są intencje lub pobudki sprawcy, a czym innym skutki działania oraz użytek (między innymi pasożytniczy), jaki z danego działania czynią inne podmioty. Ale korekty wymaga przy tym kilka wątpliwych uproszczeń, a uzupełnienia - niedopowiedzenia zawarte w zastosowanych określeniach, również będących skrótem myślowym, o czym dalej.

Wyróżnione przez Andrzeja Czajowskiego trzy subkategorie działań quasi-politycznych rzeczywiście mają pewien wspólny mianownik, uzasadniający objęcie ich określeniem zrelatywizowanym. Nie byłbym jednak pewien, czy dobrana nazwa wspólna jest najlepsza z możliwych. Przedrostek quasi- - przypomnijmy - oznacza 'prawie', ale też 'jakby', a nawet 'niby' ${ }^{25}$. Nawet w reklamie piwa wykorzystywany jest ten niuans („prawie” czyni różnicę). „Prawie” znaczy 'nieomal' (niewiele brakuje, ale jednak czegoś brakuje). „Jakby” znaczy 'niezupełnie to samo', choć jest pewne podobieństwo lub jakaś cecha wspólna z obiektem określanym jednoznacznie. „Niby” oznaczać może symulację lub niedoskonałą substytucję.

To jednak istotny aspekt, czy chodzi o surogat, substytut (w tym wypadku ersatz polityczności), zwłaszcza niepełnowartościowy (jak w innych dziedzinach „etykieta zastępcza”, „wyrób czekoladopodobny”), czy o pozór. Poprzedzając zatem przymiotnik "polityczne" tak wieloznacznym przedrostkiem "quasi-" pozostawiamy zbyt duże niedopowiedzenie. Wbrew intencjom sprecyzowania podtrzymujemy niejednoznaczność w kwestii kryteriów polityczności, nawet potraktowanej jako cecha stopniowalna, o różnym natężeniu. Być może lepszym określeniem byłoby: „s emi polityczne” (na wpół polityczne, nie w pełni polityczne)?

W wypadku działań quasi-politycznych Czajowski bierze pod uwagę działania podejmowane przez podmioty (według jego kryteriów) „niepolityczne”, działania mające

23 A. Czajowski, $X$ twierdzeń..., s. 113.

24 Por. na ten temat: M. Karwat, O upolitycznieniu twórczości i dzieł twórczych. Modelowa analiza mechanizmu, „Studia Politologiczne” 50 (Sztuka w polityce — polityka w sztuce, red. D. Przastek, K. Minkner), 2018.

25 Por. J. Mańkowski, Praktyczny słownik łacińsko-polski, Warszawa 2000, s. 206; W. Kopaliński, Stownik wyrazów obcych i zwrotów obcojęzycznych z almanachem, Warszawa 1994, s. 422. 
jednak znaczenie polityczne (chodzi o reperkusje, skutki, konsekwencje, rezonans społeczny) lub powodowane namiętnościami i zamiarami politycznymi, a także działania, którym charakter czy sens polityczny nadaje odbiór otoczenia lub instrumentalne wykorzystanie przez podmioty polityczne. Na tej zasadzie działanie artystyczne wyrażające poglądy lub emocje polityczne twórcy, a nawet manifestujące pewne intencje polityczne nie byłoby działaniem ściśle politycznym (w pełnym tego słowa znaczeniu), podobnie jak - na innej jednak zasadzie - czyn chuligański (choćby napaść rasistowska), któremu polityczny sens nadałaby dopiero interpretacja prawnopolityczna i propagandowa, a nie sama w sobie postawa nietolerancji i agresji człowieka będącego politycznym ignorantem i outsiderem, w sferze poglądów (nie mylić z uprzedzeniami, emocjami) wręcz indyferentnym politycznie.

Subtypologia działań quasi-politycznych konkretyzująca triadę Czajowskiego wydaje się uzasadnionym zniuansowaniem kwalifikacji działań składających się na mechanizm polityki jako splotu i wypadkowej działań uczestników o zróżnicowanym statusie i ukierunkowaniu aktywności. Racjonalne jest wszak założenie, iż nie każde działanie znaczące w swych skutkach, konsekwencjach politycznych jest motywowane politycznie i/lub ma intencje polityczne (cele, zamiary, plany, kalkulacje polityczne, ambicje wpływu politycznego itd., sens polityczny nadawany mu przez sam podmiot). Jednocześnie działanie o intencjach lub pobudkach politycznych może nie pociągać za sobą skutków politycznych - może być bezskuteczne samo w sobie, zignorowane lub unieważnione itd. Ważne w tej typologii jest wzięcie pod uwagę, że czym innym są intencje lub pobudki, skutki oraz użytek (między innymi pasożytniczy), jaki z danego działania czynią inne podmioty. Można by spierać się o samą terminologię, ale dla diagnozy i wyjaśniania działań kreujących politykę te niuanse mają zasadnicze znaczenie.

\section{Działania okołopolityczne}

Wyodrębnienie tego typu nie budzi wątpliwości przynajmniej z punktu widzenia wewnętrznej logiki koncepcji Czajowskiego, która jest spójna i czytelna. Ale uzasadnione jest również z perspektywy klasycznej, gdy bierzemy pod uwagę wspomniane już rozróżnienie „polityki jako takiej”, czy też „czystej polityki”, oraz polityk szczegółowych (nazywanych też merytorycznymi) oraz — w tradycji anglosaskiej - dystynkcję politics, policy, polity.

Zachodzi wszak różnica między działaniami (i decyzjami) wyrażającymi i realizującymi określone cele polityczne a działaniami wykonawczymi, pochodnymi, obsługującymi, podejmowanymi już nie przez „podmioty polityczne” (w rozumieniu Czajowskiego), lecz przez urzędy i inne instytucje publiczne - gospodarcze, edukacyjne czy kulturalne, przez służby porządkowe itd. Ich „polityczność” nie jest „samorodna” czy immanentna, lecz zaprogramowana przez dysponentów politycznych, gdyż działania te są pochodną, komponentem i instrumentem realizacji określonej wizji ideologicznej, projektu „inżynierii społecznej", a co najmniej takiego czy innego partyjnego lub rządowego programu reform, modernizacji czy restauracji. A przy tym ich mechanizm wewnętrzny (własny) 
jest inny niż działań stricte politycznych. Inna jest przecież nie tylko forma, oprawa i podstawa normatywna, lecz także „logika” działań partyjnych czy parlamentarnych, a inna logika decyzji i działań administracyjnych, policyjnych, sądowych, działań podejmowanych przez instytucje powołane do regulacji i egzekwowania wymogów technicznych, sanitarnych, estetycznych (rozmaitych inspektoratów, organów kontroli, organów wydających koncesje itp.).

Natomiast można mieć wątpliwości co do samego terminu.

„Okołopolityczne” to określenie, które i zakłada, i sugeruje, że chodzi (skoro coś niejako „otacza” politykę) o materię społeczną zewnętrzną w stosunku do polityki, dosłownie „pozapolityczną” - tyle że przylegającą („przywierającą”?) do polityki, taką, od której polityka nie może uciec, którą musi się zająć, nawet gdyby politykom wygodniej byłoby to zignorować, zrobić unik.

Sądzę, że takie określenie jest - zapewne niezamierzonym, ale niedostrzeżonym i nieprzezwyciężonym przez autora omawianej triady - echem popularnych wśród politologów, zwłaszcza o nachyleniu „prawniczym”, tęsknot za mechanicznym oddzieleniem sfery polityki i „niepolitycznych” sfer życia społecznego. W takim podejściu dostrzega się wprawdzie ingerencję polityki w sfery „pozapolityczne”, nawet konieczność i naturalność politycznej regulacji funkcjonowania gospodarki, kultury, życia religijnego, ale same w sobie problemy społeczne w tych różnych dziedzinach traktowane są (choćby podświadomie) jako zakłócenie, swoiste zanieczyszczenie sfery „czystej polityki” czy jako niewdzięczny trybut polityki na rzecz „otoczenia”. Podkreślam: nie takie są intencje podobnego podejścia, ale w skutkach staje się ono racjonalizacją politykierskiej alienacji.

Bliższy jest mi pogląd (ten uznaję za zgodny z rzeczywistością), że (1) polityka nie ma własnego „substratu”, choć wytwarza i podtrzymuje immanentny mechanizm własnego funkcjonowania (gry politycznej, rządzenia, walki o władzę lub wpływy), może też w pewnym sensie... pasożytować na problemach i perturbacjach społecznych (co widać w kampaniach wyborczych); (2) to, co ściśle polityczne (polityczne samo w sobie) - w takim czy innym rozumieniu - nie tyle „sąsiaduje”, styka się, ile przenika i splata z tym, co formalnie „niepolityczne”. Zatem do relacji między polityką a „niepolityką” znajduje adekwatne zastosowanie schemat interferencji, a nie współzależności opartej na obustronnej odrębności.

Toteż mam wrażenie, że lepszym określeniem tego trzeciego członu triady Czajowskiego byłby termin „parapolityczne”, swego czasu używany przez Artura Bodnara (obok terminu „uwikłane w politykę”), ale w jego wykładach, dyskusjach seminaryjnych, natomiast - niestety — chyba bez śladu w jego publikacjach. Grecki przedrostek „para” odnosi się do zjawisk usytuowanych na pograniczu różnych gatunkowo jednorodnych, nawet „czystych” kategorii, przekraczających kryteria delimitacji lub czyniących je problematycznymi. Znamy liczne tego przykłady: parapsychologia, formacje paramilitarne, substancje paramedyczne i inne.

Jednocześnie rozumiem, że pewne działania, które sam nazwałbym par a politycznymi, w terminologii i koncepcji Czajowskiego zostałyby zaliczone do quasi-politycznych, 
a w swojej konwencji terminologicznej sugerował się on raczej schematem „system otoczenie" i modelami "pola polityki” (Bodnara lub Bloka) niż założeniem o dosłownej rozdzielności „politycznego” i „niepolitycznego”. Nie byłbym jednak spokojny, czy ewentualni „użytkownicy” tej triady za sprawą terminologii nie zasugerują się jakoby zewnętrznym charakterem związków między polityką a tym, co ona reguluje, eliminuje lub powołuje do życia w sferze gospodarki, kultury, nauki.

\section{Pożądane uzupełnienia i uściślenia}

Jeśli nawet przystać na terminologię zastosowaną przez Czajowskiego w jego triadzie, to i tak wymaga ona opatrzenia komentarzem ukazującym pewne niuanse treści przyjętych terminów.

\section{Działania o doniosłości politycznej}

Skrót myślowy „działania o doniosłości politycznej” jest w istocie dwustopniową kumulacją. Chodzi tu o działania mające znaczenie polityczne ze względu na sam w sobie swój zasięg społeczny, tym bardziej - zwłaszcza w przypadku rozległego zasięgu - ze względu na wagę społeczną ich skutków (przy tym niezależnie od intencji podmiotu i od zgodności/niezgodności intencji ze skutkami).

Ale ponadto nie powinno umknąć naszej uwadze, iż nie tym samym jest praktyczna i obiektywna doniosłość jakichś działań (mierzona skutkami, nacechowana bezpośrednią sprawczością względnie niezależną od dostrzeżenia i „docenienia”) oraz subiektywna percepcja, społeczne poczucie doniosłości (wyrażone w zainteresowaniu i rezonansie społecznym). Choć oczywiście może być tak, że społeczne poczucie ważności odpowiada rzeczywistemu znaczeniu jakiegoś czynu czy przedsięwzięcia, natomiast obiektywna i praktyczna ważność (jako wręcz sprawczość) wzrasta właśnie ze względu na wywołane zainteresowanie i poruszenie.

A przy tym sam w sobie zasięg oddziaływania także nie musi być tożsamy z jego znaczeniem. Możliwe jest znikome znaczenie działań szeroko zakrojonych czy „wszechogarniających", jak i niewspółmierne wręcz znaczenie działań kameralnych czy marginalnych.

Wreszcie pamiętajmy też, że oprócz znaczenia ucieleśnionego w skutkach działania czy w lawinie skutków istnieje też znaczenie potencjalne, które jednak nie musi się zmaterializować, gdyż skutek działania nie jest z góry przesądzony ani zagwarantowany. Zatem do katalogu subtypów działań quasi-politycznych w dziale „działania o doniosłości politycznej” powinniśmy dorzucić subsubtyp „działania potencjalnie znaczące politycznie”. Jako przykład potraktujmy swoiste „namaszczenie” kandydata w wyborach przez duchownego, co jest aktem wymownym i sugestywnym, lecz o nieoczywistej i nieprzesądzonej z góry skuteczności oraz skali skutków. 


\section{Działania z pobudek politycznych — czy w intencjach politycznych}

Drugi skrót myślowy („z pobudek politycznych”) może być z kolei określeniem zwodniczo sugestywnym, jeśli nie uświadomimy sobie i nie weźmiemy pod uwagę istotnego niuansu, iż nie są tym samym pobudki działania, a więc motywy ${ }^{26}$ mniej lub bardziej uświadamiane i poddane samokontroli lub powodujące spontaniczność, żywiołowość działania, oraz intencje działania (jako sprzężenie nastawień w rodzaju: przychylność, życzliwość, niechęć, wrogość oraz zamiarów opatrzonych określonymi kalkulacjami) ${ }^{27}$.

Do intencji działania znajduje pełne zastosowanie inna triada, Stanisława Ossowskiego: wartości uznawane, deklarowane i realizowane; a więc uwzględnienie nietożsamości tego, czego chcemy i co zamierzamy, tego, co wypada głosić, oraz tego, co faktycznie czynimy i powodujemy, jak rzeczywiście postępujemy ${ }^{28}$. W proces motywacji i autoprezentacji mocno ingeruje mechanizm racjonalizacji, również w postaci samookłamywania.

Czy ma to znaczenie w wypadku działań obecnych w życiu politycznym? Jak najbardziej. Z koncepcji Andrzeja Czajowskiego wynika jednak, że na przykład szykanowanie pracownika, podwładnego w małej firmie ze względu na uprzedzenia polityczne to wprawdzie działanie z pobudek politycznych, lecz trudno je nazwać działaniem politycznym, skoro nie jest zaadresowane do wielkich zbiorowości, mediów, partii, organów parlamentarnych, a nie wywołuje też zamierzonego poruszenia czy skutku w stosunkach politycznych. Można się z tym zgodzić.

Zatem do katalogu działań quasi-politycznych, jaki przedstawił Czajowski, należałoby jednak dorzucić, jako kategorię osobną, choć interferującą z sąsiednimi, działania o intencjach politycznych.

Na pierwszy rzut oka mogłoby się wydawać, że jest to uszczegółowienie zbędne, gdyż intencje polityczne są wyrazem i pochodną politycznych pobudek (motywów, subiektywnych powodów do działania). Ale to związek tylko pozornie jednoznaczny lub oczywisty. Intencje polityczne działania (jednostkowego lub nawet zespołowego) mogą być konsekwencją motywów niezupełnie politycznych lub zupełnie niepolitycznych. Najprostszy przykład: osobiście motywowana wrogość wobec kogoś (jako konkurenta w karierze zawodowej, rywala w zalotach itd.) może skłonić inną osobę do zaszkodzenia mu (ale nie tylko jemu, bo i środowisku politycznemu, w którym ma oparcie, któremu zawdzięcza swój „kapitał osobisty”) przez wywołanie afery politycznej lub wspieranie dążeń do zmiany ustrojowej, która uderzy w takich ludzi - jako należących do określonej kategorii klasowej, etnicznej, wyznaniowej czy rasowej.

${ }^{26}$ Pogłębioną analizę samego pojęcia motywów (pobudek) działania ludzkiego zawiera między praca M. Ossowska, Motywy postępowania. Z zagadnień psychologii moralności, Warszawa 2002. Zob. też A. Maslow, Motywacja i osobowość, Warszawa 1990; J. Reykowski, Z zagadnień psychologii motywacji, Warszawa 1970 (wykład porządkujący, który bynajmniej się nie zestarzał); K. Obuchowski, Psychologia dążeń ludzkich, Warszawa 1983.

27 Por. na ten temat K. Obuchowski, Człowiek intencjonalny, Warszawa 1993.

28 Zob. S. Ossowski, Dzieła, t. 3. Z zagadnień psychologii społecznej, Warszawa 1967, fragment pt. Konflikty niewspótmiernych skal wartości. 
Ale również w wypadku, gdy mamy do czynienia z działaniem motywowanym politycznie i podyktowanym bezsprzecznie politycznymi intencjami (takimi jak zamiar zwalczania lub poparcia jakiejś siły politycznej, podważenia lub utrwalenia panującego porządku, uzyskania udziału w sprawowaniu władzy itp.), to abstrakcyjne rozgraniczenie ma sens... praktyczny. Zarówno w interpretacji działań przez uczonego, publicystę-komentatora, jak i w kwalifikacji czynów na przykład przez prokuratora czy sędziego nierzadką sytuacją jest jasność tylko w jednej kwestii, a zagadka lub dylemat interpretacyjny w drugiej, na przykład znamy pobudki, nie jesteśmy jednak pewni intencji lub na odwrót.

\section{Działania upolityczniane}

„Upolitycznione” to w domyśle takie, którym sens (wydźwięk) polityczny lub znaczenie polityczne dla otoczenia nadaje kto inny niż sam sprawca (podmiot).

Zastosowanie takiej kwalifikacji byłoby proste, gdyby nie złożoność i wielorakość stosunku sprawstwa. Nazywając kogoś podmiotem działania, musimy mieć jasność i świadomość, czy chodzi o inspiratora, pomysłodawcę lub mocodawcę (na przykład patrona, protektora, sponsora, zleceniodawcę, ale i na przykład podżegacza), czy koordynatora cudzych działań albo wiązki działań tworzących kooperację, czy o bezpośredniego wykonawcę ${ }^{29}$. A przecież w grę może wchodzić również dyskontowanie cudzych działań na zasadzie okazji, pretekstu lub narzędzia wpisanego w bardziej złożony plan własny ${ }^{30} \mathrm{~W}$ każdym wypadku kto inny „upolitycznia” i dokonuje tego w sposób tylko sobie właściwy. Nie od rzeczy byłoby również pamiętać, iż często ma miejsce upolitycznienie przez nikogo niezamierzone, jako tendencja żywiołowa uruchomiona splotem okoliczności.

Andrzej Czajowski trafnie zauważa, że kwalifikacja czyichś działań jako politycznych może mieć charakter instrumentalny i pretekstowy ${ }^{31}$ (na przykład jako pretekst do dyskredytacji) oraz że działania (w intencjach sprawcy) politycznie indyferentne lub neutralne czy nawet „apolityczne” mogą zostać wkomponowane w cudze akcje propagandowe, agitacyjne, marketingowe, także na zasadzie nadużycia - w postaci skrajnie tendencyjnej interpretacji, nadinterpretacji, dezintepretretacji. Wprawdzie autor nie użył tego słowa, ale dał do zrozumienia, że ma tu miejsce niejako pasożytnicze przechwycenie czy „skonsumowanie” czyjegoś działania. Ale wtedy podmiotem działania podchwyconego i niejako przechwyconego zaczyna być nie tyle bezpośredni sprawca czy na przykład inspirator, ile jego beneficjent, dysponent, użytkownik, „konsument”.

29 Zob. C. Znamierowski, Wina i odpowiedzialność, cz. 1, Warszawa 1957. Ontologiczno-prakseologiczna typologia sprawstwa znajduje zastosowanie w prawnych kwalifikacjach czynów w kategoriach sprawstwa kierowniczego, wykonawczego, pomocnictwa, poplecznictwa itd. Por. M. Cieślak, Polskie prawo karne. Zarys systemowego ujęcia, Warszawa 1995, rozdz. XX. Formy wspótuczestnictwa przestępnego.

30 Zob. na ten temat M. Karwat, Teoria prowokacji. Analiza politologiczna, Warszawa 2007, fragment pt. Prowokacja pasożytnicza.

31 A. Czajowski, X twierdzeń..., s. 111, 113. 
W sumie trudno nie zgodzić się z zastrzeżeniem, że wspólna nazwa „działania polityczne" nie pasuje jednocześnie do czynów czy przedsięwzięć z założenia służących celom politycznym i/lub spełniających polityczne (na przykład ustrojowe) funkcje oraz do działań politycznie „zawłaszczonych” przez podmioty inne niż sprawcy działający z własnych pobudek, z sobie właściwym zamiarem i z założenia „na własne konto”. O tych drugich rzeczywiście można mówić, że zostały upolitycznione.

Tyle tylko, że to nie wyczerpuje spektrum możliwych sytuacji. Istnieje przecież coś takiego jak „samoupolitycznienie” (rezultat trwałego lub okolicznościowego zaangażowania politycznego w roli formalnie niepolitycznej), kiedy to podmiot działania formalnie niepolitycznego (na przykład artystycznego, naukowego, religijnego, gospodarczego) sam nadaje temu działaniu wymowę polityczną i polityczne znaczenie, sam rozmyślnie i ostentacyjnie włącza lub tylko z lekkim kamuflażem wplątuje swoje działanie (na przykład publikację, instalację artystyczną, nabożeństwo) w grę polityczną. W takim wypadku również ujawniają się pewne niuanse. Najczęściej ma miejsce instrumentalne nadanie czemuś „niepolitycznemu” kontekstu politycznego, a nawet politycznej formy. Ale może to być zarówno próba osiągnięcia autentycznych i samoistnie religijnych, artystycznych czy innych celów przez czynnik wsparcia czy nacisku politycznego, jak i nadużycie pewnych wartości samoistnych, na przykład sztuczne zapewnianie sobie promocji, sukcesu w dziedzinach „niepolitycznych”, także dla dzieł pseudoartystycznych, pseudoreligijnych itp., przez wplątanie tego w politykę.

„Upolitycznianie” działań „niepolitycznych” może mieć charakter umyślny lub niezamierzony i nawet przypadkowy (jak to bywa w wielu aferach gospodarczych i skandalach obyczajowych, w konfliktach na tle ekonomicznym czy ekologicznym); ale może też być efektem nieuniknionym, a niekontrolowanym przez nikogo. To nietożsame, a skomplikowane rodzaje uwikłania ${ }^{32}$.

Typologię (triadę) Andrzeja Czajowskiego uzupełniłbym jeszcze - koniecznie o kategorię działań metapolitycznych. O ile działania stricte polityczne są działaniami wprawdzie dotyczącymi warunków funkcjonowania całego społeczeństwa i państwa, regulującymi lub naruszającymi równowagę społeczną, ciągłość funkcjonowania wspólnoty, podyktowanymi jednak tak czy inaczej partykularnymi interesami i stronniczymi poglądami określonej siły społecznej, o tyle działania metapolityczne to takie, które związane są z próbą ustanowienia i egzekwowania reguł gry politycznej, standardów praworządności, „poprawności politycznej”, dobrych obyczajów, mechanizmów kontroli prawnej i społecznej, wzorców i procedur wzajemnego ograniczenia i samoograniczenia sił politycznych w ich dążeniach i formach działania politycznego, wreszcie ochrony i gwarancji praw uczestników życia politycznego ${ }^{33}$. To istotna różnica - między normami i wysiłkami wyrażającymi partykularną wolę (także samowolę) polityczną a (jakby

32 Analizę pojęcia i mechanizmu uwikłania oraz typologię jego form i okoliczności zawiera mój artykuł Uwikłanie jako korelat i koszt uczestnictwa, [w:] Metafory polityki (4), red. B. Kaczmarek, Warszawa 2013.

33 Zob. M. Karwat, Polityka rzeczowa, stronnicza i metapolityka, „Studia Politologiczne” 8 (Współczesne teorie polityki - od logiki do retoryki, red. T. Klementewicz), 2004. Charakterystykę statusu i funkcji norm prawnych (w państwie praworządnym) jako właśnie metapolitycznych, choć nie używając tego określenia, rozwijał Tadeusz Zieliński w swych książkach — refleksjach Rzecznika Praw Obywatelskich. 
to określił Stanisław Ehrlich) ,wiążącymi [wszystkich - M.K.] wzorami zachowania”34. Ten metapolityczny rodzaj reguł, standardów i działań służących ich usankcjonowaniu stał się trwałym (choć raz po raz zagrożonym, podważanym) elementem krajobrazu politycznego w demokracji liberalnej. Kryzys polskiej demokracji zaś naocznie ukazał, jakie są konsekwencje i koszty powszechnego w społeczeństwie niezrozumienia różnicy między polityką a metapolityką.

\section{Podsumowanie}

Przedstawione uwagi i komentarze do typologii-triady Czajowskiego ukazują chyba wyraźnie, jak kluczową kwestię podniósł autor i jak inspirująca okazuje się jego systematyka. W dydaktyce nauk politycznych w ogóle (nie tylko w ramach przedmiotu „teoria polityki”) ta systematyka powinna być zaliczana do kanonu. Politolog, który nie znałby, nie przyswoiłby sobie tych niuansów lub zlekceważył subtelności uchwycone tą typologią w złożonej morfologii życia politycznego, byłby kiepskim analitykiem lub komentatorem polityki.

\section{Bibliografia}

Blok Z., O polityczności, polityce i politologii, Wydawnictwo Naukowe WNPiD UAM, Poznań 2009.

Bodnar A., Decyzje polityczne. Elementy teorii, PWN, Warszawa 1985.

Bodnar A., Ekonomika i polityka. Podstawowe zależności, PWN, Warszawa 1980.

Carl Schmitt a współczesna myśl polityczna, red. R. Skarzyński, DW ELIPSA, Warszawa 1996.

Carl Schmitt. Wyzwanie polityczności, red. Ch. Mouffe, Wydawnictwo Krytyki Politycznej, Warszawa 2011.

Cieślak M., Polskie prawo karne. Zarys systemowego ujęcia, PWN, Warszawa 1995.

Czajowski A., X twierdzeń o polityce, Wydawnictwo Adam Marszałek, Toruń 2015.

Czajowski A., Decydowanie w polityce, Wrocławskie Wydawnictwo Naukowe Atla 2, Wrocław 2013.

Czajowski A., Polityczność działań dziennikarza w świetle teorii konfliktu społecznego, „Studia Politologiczne" 37 (Polityczność i polityka w refleksji teoriopolitycznej, red. B. Kaczmarek, M. Karwat), 2015.

Czym jest teoria w politologii?, red. Z. Blok, DW Elipsa, Warszawa 2013.

Ehrlich S., Wiążace wzory zachowania. Rzecz o wielości systemów norm, PWN, Warszawa 1995.

Ginneken J. van, The Psychology of Power. Temptations at the Top, London 2015.

Gulczyński M., Politologia. Podręcznik akademicki, wyd. Almamer. Wyższa Szkoła Ekonomiczna, Warszawa 2010.

Karwat M., Cecha polityczności i dziedzina teorii polityki, [w:] Carl Schmitt a współczesna myśl polityczna, red. R. Skarzyński, Warszawa 1996.

Karwat M., O karykaturze polityki, Muza, Warszawa 2012.

Karwat M., O niezbędnym dopetnieniu optyki kratycznej w naukach o polityce, [w:] Nauki o polityce 2.0. Kontrowersje i konfrontacje, red. S. Sulowski, Warszawa 2018.

Karwat M., O statusie pojęcia „polityczności”, „Studia Politologiczne” 37 (Polityczność i polityka w refleksji teoriopolitycznej, red. B. Kaczmarek, M. Karwat), 2015.

Karwat M., O upolitycznieniu twórczości i dzieł twórczych. Modelowa analiza mechanizmu, „Studia Politologiczne” 50 (Sztuka w polityce - polityka w sztuce, red. D. Przastek, K. Minkner), 2018.

\footnotetext{
34 S. Ehrlich, Wiążące wzory zachowania. Rzecz o wielości systemów norm, Warszawa 1995.
} 
Karwat M., Polityczność i upolitycznienie. Metodologiczne ramy analizy, „Studia Politologiczne” 17 (Wyjaśnianie polityki, red. J. Błuszkowski, J. Zaleśny), 2010.

Karwat M., Polityka rzeczowa, stronnicza i metapolityka, „Studia Politologiczne” 8 (Współczesne teorie polityki - od logiki do retoryki, red. T. Klementewicz), 2004.

Karwat M., Teoria prowokacji. Analiza politologiczna, PWN, Warszawa 2007.

Karwat M., Uwikłanie jako korelat i koszt uczestnictwa, [w:] Metafory polityki (4), red. B. Kaczmarek, DW Elipsa, Warszawa 2013.

Klementewicz T., Rozumienie polityki. Zarys metodologii nauki o polityce, DW Elipsa, Warszawa 2010.

Kopaliński W., Słownik wyrazów obcych i zwrotów obcojęzycznych z almanachem, Wiedza Powszechna, Warszawa 1994.

Krauz-Mozer B., Teorie polityki, PWN, Warszawa 2005.

Mańkowski J., Praktyczny słownik łacińsko-polski, Prószyński i S-ka, Warszawa 2000.

Maslow A., Motywacja i osobowość, IW PAX, Warszawa 1990.

Minkner K., Główne problemy konceptualizacji pojęcia polityczności, „Studia Politologiczne” 37 (Polityczność i polityka w refleksji teoriopolitycznej, red. B. Kaczmarek, M. Karwat), 2015.

Minkner K., Problem polityczności jako metateoretyczne wyzwanie dla politologii, „Athenaeum” 2014, nr 43. Mościcki T., Polityka teatru. Eseje o sztuce angażującej, Wydawnictwo Krytyki Politycznej, Warszawa 2008. Mouffe Ch., Agonistyka. Polityczne myślenie o świecie, Wydawnictwo Krytyki Politycznej, Warszawa 2015.

Mouffe Ch., Polityczność. Przewodnik Krytyki Politycznej, Wydawnictwo Krytyki Politycznej, Warszawa 2008.

Mroziewicz K., Delirium władzy, Fundacja Oratio Recta, Warszawa 2019.

Nauki o polityce 2.0. Kontrowersje i konfrontacje, red. S. Sulowski, DW Elipsa, Warszawa 2018.

Obuchowski K., Człowiek intencjonalny, PWN Warszawa 1993.

Obuchowski K., Psychologia dążeń ludzkich, PWN, Warszawa 1983.

Ossowska M., Motywy postępowania. Z zagadnień psychologii moralności, Książka i Wiedza, Warszawa 2002.

Ossowski S., Dzieła, t. 3. Z zagadnień psychologii społecznej, PWN, Warszawa 1967.

Polityka/polityczność. Granice dyskursu, red. B. Krzysztan, W. Ufel, M. Zieliński, Oficyna Wydawnicza Atut, Wrocław 2016.

Polityka i polityczność. Problemy teoretyczne i metodologiczne, red. A. Czajowski, L. Sobkowiak, Wrocławskie Wydawnictwo Naukowe Atla 2, Wrocław 2012.

Rancière J., Dzielenie postrzegalnego. Estetyka jako polityka, Korporacja Ha!art, Kraków 2007.

Rancière J., Na brzegach politycznego, Korporacja Ha!art, Kraków 2008.

Reykowski J., Z zagadnień psychologii motywacji, PWN, Warszawa 1970.

Ryszka F., O pojęciu polityki, PWN, Warszawa 1992.

Schmitt C., Teologia polityczna i inne pisma, Znak, Kraków 2000.

Szalkiewicz W.K., Gałązka W., Żądza rzadzenia. O władzy, polityce i politykach, Trio, Warszawa 2010.

W poszukiwaniu polityczności, red. E. Jurga-Wosik, S. Paczos, R. Rosicki, Wydawnictwo Naukowe WNPiD UAM, Poznań 2014.

Zieliński T., Czas prawa i bezprawia. Myśli niepokorne kustosza praw, DW ABC, Warszawa 1999.

Zieliński T., Droga do Ziemi Obiecanej, Książka i Wiedza, Warszawa 2002

Zieliński T., Labirynt praw i obyczajów. Zapiski z końca XX wieku, Książka i Wiedza, Warszawa 2001.

Ziembiński Z., Logika praktyczna, PWN, Warszawa 2014.

Znamierowski C., Wina i odpowiedzialność, PWN, Warszawa 1957. 


\section{About political and related activities. Commentary on the typology of Andrzej Czajowski}

Keywords: politics, politicity, politicization, political theory, strictly political actions, quasi-political actions, surround-political actions

Summary

The political sphere of social life creates not strictly political actions undertaken by policy-holders (specialized in the struggle for power and the art of governance, constituting or changing the political order, regime), but also quasi-political actions undertaken by big social groups, communities and social movements, even by individuals interested in certain decisions, exerting pressure on the governing and other political forces (also for non-political purposes) and surround-political actions undertaken in politically-inspired or controlled and programmed offices, public institutions in the course of management, judgment, enforcement of the legal order. Quasi-political actions include: politically-motivated actions, politically-important actions (also relevant irrespective of the subject's motives and intentions) and politicized actions - politicized by how they are perceived and exploited by the Perpetrator's surrounding entities. So is the typology of Andrzej Czajowski, which is worth complementing the meta-political actions - related to the establishment and enforcement of rules and standards of the political game, governance, forms of social and legal control and self- or mutual limitation of political forces? 